decision-makers. INSONA spreads the message of conservation, as envisaged inter alia by UNEP, the Nairobi-based ELC (Environment Liasion Centre-International), UNESCO, FAO, IUCN, WWF, CITES, WCB (World Council For The Biosphere) and allied ISEE (International Society For Environmental Education), and IEEF (International Environmental Education Foundation), and has established particularly close reciprocal links with the globallyoriented Foundation for Environmental Conservation (situated near the International Airport of Geneva, Switzerland).

INSONA will cooperate with other institutions and societies having similar objectives*, and will seek affiliation to national and international bodies to promote advancement of study and research in natural and applied sciences. It will also provide opportunities for field observations and study to the younger generation, and will create an awareness about appreciation of Nature and its conservation. Moreover, it will endeavour to bring together the 'common man' (or woman) and scientists from various disciplines, towards improved understanding of Our Biosphere. That the general public and the scientist should work together to regulate disturbed environments is a cry of time; to the extent that we achieve this, it will contribute significantly to the lasting welfare of Mankind (Gaekwad, 1976).

We need support from an army of Patrons, well-wishers, and volunteers, in combating the tremendous menace to the endangered global environment and wildlife. We appeal to the legion of Nature-lovers and prosperous Charitable Trusts, Foundations, and INGOs, to establish effective partnerships and extend generous funding support for our task to eradicate environmental illiteracy, through Environmental Awareness, in all the world's normallyinhabited continents. These environmental espects were dear above all to INSONA's late President, who passed away on 1st September 1988 (see the 'Fond Tribute' of Oza \& Polunin, 1988), and we share his aspirations for an ongoing world in which Mankind and Nature live in harmony as parts of an ever-viable Biosphere.

\footnotetext{
* Including, we would hope, the recently-established International Vernadsky Foundation and its likely offshoot the stronglyrecommended International Centre for Biosphere Studies, see Environmental Conservation, 15(2), pp. 177 \& 187-9, 1988, and in press. - Ed.
}

\section{REFERENCES}

GaEkwad, F.P. (1976). Indian Society of Naturalists. Environmental Conservation, 3(4), p. 254.

Gaekwad, F.P. \& Oza, G.M. (1981). Save Our Biosphere. Environmental Conservation, 8(2), pp. 117-8, fig.

OzA, G.M. (1979). Baroda - Naturalists' Headquarters. Everyman's Science, 14(3), pp. 100-2.

OzA, G.M. (1982). Save Trees, Save Our Biosphere! Environmental Conservation, 9(3), pp. 255-6, fig.

OzA, G.M. (1983). An Indian View of Man and Nature. Environmental Conservation, 10(4), pp. 331-5.
OzA, G.M. (1985). 'Guardians of the Trees'. Environmental Conservation, 12(2), 182-3, fig.

OzA, G.M. (1986a). 'Save Our Biosphere' Campaign for Wildlife Conservation. Environmental Conservation, 13(1), pp. 75-6. 3 figs.

OZA, G.M. (1986b). INSONA's Contribution to Environment and Peace-WED 1986. Environmental Awareness, 9(3). pp. 93-5. fig. (on 2 nd page of cover).

OzA, G.M. (1987). INSONA and Environmental Awareness. Environmental Conservation, 14(2), p. 181, 2 figs.

OzA, G.M. \& Polunin, N. (1988). Fond tribute to an ardent conservationist: H.H. Fatehsinghrao P. Gaekwad, 1930-88. Environmental Conservation, 15(3), pp. 271-2, fig.

Polunin, Nicholas (1988). The Foundation for Environmental Conservation: auspices, objectives, and needs. Environmental Conservation, 15(1), pp. 71-3.

VAllentyNe, J.R. (1982). Note from a 'Save Our Biosphere' sticker distributor. Environmental Conservation, 9(2). p. 111.

Gunavant M. Oza, Reader in Botany
The Maharaja Sayajirao University of
Baroda;
General Secretary of INSONA \& Founding
$\quad$ Editor of Environmental Awareness
Oza Building
Salatwada
Baroda 390001, India.

\section{Appendix: INSONA Membership}

Any person who is interested in the activities of the Society shall be eligible to be a Member, the categories of Membership being as follows:

(a) Patrons: Any individual or institution contributing Rs 5,000 (US $\$ 500$ or $£ 250$ for individuals in other countries) or more to the Society.

(b) Life Members: Any individual who pays an entrance fee of Rs 25 (US $\$ 2$ or $£ 1$ ) and a life membership of Rs500 (US $\$ 200$ or $£ 100$ for individuals in other countries) or more to the Society.

(c) Ordinary Members: Any one who pays an entrance fee of Rs 25 (US $\$ 2$ or $£ 1$ ) and an annual subscription* of Rs50 (US $\$ 20$ or $£ 10$ for individuals in other countries) or as decided by the Executive Committee of INSONA from time to time.

(d) Institutional Membership: Any institution or association that is interested in promoting the aims and objectives of the Society and pays an entrance fee of Rs 25 (US $\$ 2$ or $£ 1$ ) and a subscription of Rs 200 (US $\$ 100$ or $£ 50$ in other countries) annually*.

Besides the above categories of Membership there is the purely honorific one of Fellow of INSONA, which is decided by election by the Executive Committee of INSONA sitting in full session, the quorum being a clear majority of the Board members.

* Annual subscriptions to INSONA should be received at the above address by the middle of April.

\title{
Environmental Impact of Dutch Military Activities (Correcting Note)
}

We regret that, in the above-mentioned paper by Paul J.M. Vertegaal (of Haarlem, The Netherlands) which was published in our Spring issue of this year (16(1), pp. 54-64), on page 59 , in the heading to Table IV, the second source after Jong (1986) was inadvertently omitted. This 'second source', Netherlands (1988b) - correctly cited in the References on page 64 - was the one from which the 1987 figures were derived. - Ed. 